\title{
Power, Conflict and Democracy: The Analytical Framework
}

Olle Törnquist ${ }^{1}$

The point of departure for the Power, Conflict and Democracy Programme (PCD) is the critique of the two conventional explanations for the problems of democratisation in the global South for being empirically mistaken and based on narrow and static theory. ${ }^{2}$ We argue that the root causes for the crisis of democratisation are neither poor application of the mainstream model (emphasising elitist pacts and institution-building in return for more privatisation and self management), nor that democracy is premature due the lack of sufficient preconditions. Rather, the more fundamental dilemma is the depoliticisation of democracy and the fact that the paradigms are unable to conceptualise the problems and options involved. This inability is because the proponents of both the dominant arguments agree on a narrow definition of democracy in terms of freedoms and fair elections - and then either neglect the basic conditions or say they have to be created beforehand by other means. The result is that both paradigms exclude by definition approaches that focus less on democratic rules of the game in themselves and more on how these institutions may be used and expanded in favour of improved social, economic and other conditions. Given that such social democratic oriented paths have been quite important, especially in the transition of the previously poor Scandinavian countries into welfare states, and that adapted versions are now gaining ground in paradigmatic cases such as Brazil, there is an obvious need to widen the perspective.

The challenge is thus to develop a theoretical framework that allows for empirical analysis of the problems and options of democratic politics in favour of rights based (social democratic) peace and development, not just studies of the market and self management driven liberal (and illiberal) mainstream .

Such a more inclusive analytical framework needs to facilitate both comprehensive analyses on the level of countries and case studies 
on the level of critical factors and dynamics. On the first level, we shall expand on attempts to combine assessments of democratic institutions and studies of the political power and capacity of the various actors and movements involved. These attempts draw on broad surveys such by the Demos team (Priyono et.al. 2007 and Demos 2008) as well as comparative case studies (e.g. in Harriss et.al. 2004). In the second case, we focus on a number of more specific problems that relate to the elitist incorporation of people into politics at the expense of popular representation. The latter approaches benefit from a recent effort to conceptualise the core dimensions and dynamics of representation (Törnquist et.al. forthcoming). This does not only apply to the context of "regular" politics but also to efforts at democratic conflict transformation (Uyangoda 2005, 2007).

\section{Comprehensive analyses}

The general problems involved in comprehensive studies of power and democracy are particularly serious in the global South. On the one hand, the tendency in most assessments is to focus on separate elements of democracy. These include basic freedoms, human rights, rule of law, elections, governance and civil society. Typically, descriptive, globally standardised and often static measurements are generated of each dimension. Consequently the studies usually fail to relate the factors to each other and to also consider actors in quite diverse, unevenly developed and changing contexts. ${ }^{3}$ Moreover, the models that really do also consider actors and conditions tend to be limited to quite general indicators. ${ }^{4}$ On the other hand, the approaches concentrating instead on social movements and civic organisations rarely relate to democratic theory and institutional frameworks. Hence, there is an urgent need to combine studies of movements, actors, and institutions.

In addition, country level studies are abundant but tend to be poorly grounded. There is a lack of local level studies in theoretical and comparative perspective. Equally serious, commercially driven and politically partisan oriented surveys on opinions and attitudes multiply, especially in new or reborn electoral democracies as Indonesia. Tragically, this is at the expense of impartial data banks and reviews of existing knowledge. Hence, easily accessible formal sources and expert statements are the most often consulted data. This is in spite of the fact that the powerful groups and institutions are the only ones that keep some (but usually unreliable) records, that the oral tradition and informal agreements dominate, and that as usual the poor majority do not write their memoirs. Most seriously, many of these challenges are not only due to the hegemony of poorly contextualised western scholars and their "local" counterparts, but also the poor standard of theory, data collection and the fragmentation of available knowledge and ongoing research.

A partial exception from these trends is the democracy assessments promoted by the International Institute for Democracy and Electoral Assistance (IDEA) on the prime basis of the British "democratic audit", 
pioneered by David Beetham and others (Beetham et.al. 2002). It is true that rather static descriptions of institutional performance and opinions among people continue to dominate within this framework at the expense of integrated analyses of actors, mechanisms and processes.

But there are also improvements, such as in the recent South Asia Survey, (CSDS 2007). Moreover, the weaknesses do not undermine the theoretical points of departure in Beetham's work (1999) on the relations between democracy and human rights.

\section{An alternative perspective}

The most powerful of Beetham's argument is that the ends and means of democracy must be held apart. Democracy is a disputed concept, but most scholars agree on the aims in terms of popular control of public affairs on the basis of political equality. Similarly, there is rather general agreement that this aim presupposes equal right to participation, the authorisation of representatives and officials and their representation of the people, which in turn calls for responsiveness and accountability, transparency and some basic solidarity among people. Finally, much of this requires, overlaps with and contribute to human rights. More controversially, Beetham et.al. also argue (and we agree) that the aims are not absolute but relative, and that the extent to which they are fulfilled depend on the qualities of a number of means. These means remain to be identified and do not themselves constitute democracy but may "only", at best, contribute to the aims of democracy. With this, democracy is no longer a black box that is either in place or not. Rather, democracy is a more or less successful multi-dimensional process - an interaction between large numbers of crucial factors and actors in different contexts aiming at politically equal popular control of public affairs.

Similarly important, these theoretical points of departure enable the recognition of two seemingly contradictory but in reality complementary and most important characteristics. The first characteristic is that the basic dimensions of democracy are universal. This is against cultural relativist arguments about qualitative differences in the South. The universality is because the aims of democracy are defined on the basis of political and philosophical theory (and need to be contented at that level), and because the general means in turn are identified in terms of what is absolutely necessary to reach the aims. The second characteristic is that it is equally important to analyse the actors' will and capacity to promote and use locally adapted versions of the universal building stones in different contexts of institutions and relations of power. This is against world wide measurements of static indicators only.

These two characteristics constitute the crucial link between institutions, actors and relations of power. The actors need to both navigate the conditions and relate to the institutions - which in turn opens up for analysis of processes and dynamics. This does not mean that "everything is important" and that theory of institutions, structures, 
and social movements can be added to each other. Rather, the focus is on the intrinsic means to promote the aims of democracy, including people's capacity to use them. These intrinsic means are the crucial dimensions and dynamics that we need to employ relevant parts of theories about institutions, structures and actors to understand and explain.

So what are the intrinsic means of democracy? And what is the best way of studying how they are embedded in contextual institutions and relations of power? The definition of what means that are absolutely necessary to foster democracy is ultimately an empirical question about what people deem to be public affairs and what has proved crucial to generate equal popular control of them. While there is no doubt that factors such as social and economic equality and extensive public resources are conducive to democracy, there are three reasons for why one should focus on the minimal conditions. First, because otherwise the definition of democracy would be so demanding that very few democracies would exist in the first place. Second, because most of the demanding conditions would need to be created undemocratically (ahead of democracy) and could not be fostered by the minimum tools of democracy. Third, because people with different views and interests about matters such as social and economic equality and public resources need to agree on basic standards of democracy if these formal and informal constitutions shall serve as a means for handling their conflicts.

\section{The intrinsic institutions}

What minimum conditions have proved indispensible, theoretically and empirically? Beetham et.al. (2002) suggested some 85 institutions within three broad categories. The first category was constitutionalism by way of the judiciary (equal citizenship, rule of law, justice, civil and political rights and socio-economic rights in terms of basic needs and regulations). The second was popular sovereignty by way of legislative and executive government (democratic elections, representation and responsive and accountable government and public administration). The third was civic engagement by way of civil society (free and democratically oriented media, art, academia, associational life and other forms of add additional popular participation including consultation and various forms of "direct democracy").

In the framework that Demos used for its recent country wide resurvey on democracy in Indonesia, the 85 institutions had been boiled down to $32 .{ }^{5}$ This is in addition to questions about the actually existing people, demos, since it is far from clear that there is, for instance, a generally accepted "Indonesian people", given regional and communal divisions. (Törnquist 2008 b)

In this framework there are also more specific and comprehensive criteria to analyse the extent to which various arrangements have "produced" democracy. Instead of asking about the general means of democracy in the country at large, the first step is to specify in what geographical and 
frontlines of democratisation that the assessments are made. Thereafter a distinction is made between formal rules and informal rules and regulations, and questions are asked about (a) the existence of formal arrangements to promote each of the requested means of democracy; (b) the performance of the existing formal as well as informal arrangements; (c) their geographical scope; and (d) their substantive scope (i.e. to what extent matters which are deemed to be of public concern are actually included). Finally an index is developed to combine the various measures of the extent to which each instrument really contribute to democracy. ${ }^{6}$

\section{Actors' will and capacity}

As already pointed out it is insufficient to only assess the quality of the institutional building blocks. Just like a sailor in rough weather must be able to understand and adjust to the ship, wind and sea, one must also consider the will and capacity of the actors to use and promote the instruments given the institutional and structural conditions. This is to enable analysis of the dynamics of democracy and the possibilities to foster it in order to alter relations of power to thus promote better conditions.

A simple and fruitful way (that has been tested out by Demos) is to operationalise actors' will by asking in relation to what institutions that the actors are in a strong or weak position and whether the actors promote, use, abuse and/or avoid them. It is more complicated to operationalise the actors' political capacity. Previous studies and theories about political power, movements and other actors point to five clusters of parameters. These have been discussed elsewhere in more detail (Törnquist 2002, 2008 a, 2008 b, Harriss et.al. 2004, and Stokke 2002). The first variables are to indicate if the actors are present rather than marginalised on central and local levels and in parts of the political landscape such as the business sector, interest- and issue groups, self management (including co-operatives), parties, parliaments, and executive public institutions. These indices relate to theories about exclusion and inclusion, differences between new and old movements, sectoral fragmentation, centre versus periphery, and the opportunity structure in terms of the relative openness and closeness of politics in general. Alternatively one may analyse similar factors by drawing on Pierre Bourdieu's (Wacquant 2005, Stokke 2002) concept of fields of interrelated actors and relations of power.

A second cluster of variables relate more exclusively to Bourdieu's focus on how the actors within the just mentioned "fields" are able to transform their different sources of power in terms of economic, social and cultural capital ${ }^{7}$ into legitimacy and authority - to thus gain symbolic power and political influence (ibid).

The third type of indicators is to analyse whether and how actors are able to politicise those of their concerns and aspirations that are not personal, i.e. to put their issues, interests and ideologies on the political agenda. This relates to theories inspired by, for instance, Jürgen Habermas about the public sphere, Antonio Gramsci about hegemony, 
Pierre Bourdieu about "habitus" (internalised norms, understandings and patterns) and the general importance of culture. But the same indicators connect also to analyses of increasingly fragmented priorities and agendas, especially among actors in civil society and related difficulties to generate common platforms (e.g. Törnquist 2002 and 2008a).

The fourth group of parameters is to capture whether and how the actors are able to organise and mobilise support. This is directly linked to theories of power, politics and movements such as advocated by Nicos Mouzelis (1986) and Sydney Tarrow (1994), distinguishing between incorporation into politics by way of elitist populism, clientelism and alternative patronage - and related political financing - or more integrated by way of networks and or comprehensive organisation from below. But it relates also to analyses such as by Mahmood Mamdani (1996), Partha Chatterjee (2004), Houtzager et.al (2007) and Harriss (2006) of different inclusion of citizens, subjects and denizens without capacity to use most other rights than that to rally behind and vote for or against leading politicians.

Fifth the roadmaps to analyse whether and how the actors are able to approach various governance institutions. The major source of inspiration is the growing consensus of the key problem of elitist dominance and the poor state of popular representation in spite of exciting attempts to initiate new routes. Hence there is a special need for in depth studies within this field, to which we shall return shortly.

\section{Improvements and applications}

The above outline will serve as an initial and tentative framework to be improved upon in comprehensive analyses of the general problems and options of democratic advances towards rights based (social democratic) peace and development in Indonesia and Sri Lanka. Sri Lanka and Indonesia are crucial contrasting cases of the first and second paths to democracy in the global South; contrasting cases which anyway, moreover, have many problems in common. The first round of analyses will focus separately on Indonesia and Sri Lanka; comparisons come later.

The insufficient supply of sources and scattered data provide a special challenge. In Indonesia, the point of departure is Demos' surveys (Priyono et.al. 2007, Demos 2008, Törnquist 2008 b). These (and forthcoming) surveys generate unique information that is based on the assessment of grounded experts on problems of democracy along key frontlines in all the provinces of the country. While the Demos collective follows up the conclusions that are of immediate political importance by developing recommendations and facilitating implementation with politically active pro-democrats, the PCD Programme provides a framework for more comprehensive analysis and comparisons of the empirical data at large. The latter expansion will be done through analysis of the original data in view of relevant additional results from other already concluded or ongoing Indonesian and international studies. 
In Sri Lanka the point of departure is relevant parts of the report on the State of Democracy in South Asia (CSDS 2007). Unless special funds are provided, it will not be possible to supplement this study with similarly extensive assessments by grounded experts as those provided by the Demos surveys in Indonesia. Yet, the PCD researchers will add information to the South Asia Survey that relate to our framework by drawing as far as possible on supplementary results from concluded and ongoing separate projects.

Finally the two comprehensive studies will provide inputs for concluding comparisons. But before that, and most crucially, they may also serve as continuously developed empirical frameworks for the identification and integration of specific thematic studies of particularly important problems.

\section{Special focus on representation}

The thematic studies shall focus on key aspects of the factors behind the crisis of democratisation in the global South - i.e. the depoliticisation of public affairs and the insufficient popular representation. The relatively autonomous political relations between state and people have deteriorated and the new civil society related participation is no alternative on its own. The public resources and capacities vested with the state have been hollowed out. Economic and political power in countries such as Sri Lanka and Indonesia rests primarily with actors related to "informalised" state institutions and private business. The relations between state and people are increasingly mediated by on the one hand communal, patronage- and network based groups and by on the other market institutions, neither of which are subject to democratic control. The major challenge is thus to analyse the dynamics of the actually existing mediation as well as the potentials and efforts at improved popular representation.

\section{Approaches to representation}

Such analyses in turn call for fruitful analytical tools. Representation is a complex and contented concept. We shall draw on a recent attempt to develop an inclusive framework on the basis of theory and empirical studies of efforts to counter the demise of popular politics (Törnquist et.al forthcoming). As outlined by Pitkin (1967), representation presupposes a representative, the represented, something that is being represented and a political context. The dynamics is primarily about authorisation and accountability, which presuppose transparency and responsiveness. That which is represented may be substantive, descriptive and/or symbolic. Substantive representation is when the representative "acts for" the represented, for instance a leader advancing the interests of workers. Descriptive representation is when an actor "stands for" the represented by being "objectively" similar. For instance, a woman represents women and a resident in a village represents the other villagers. Symbolic representation, finally, is when an actor is perceived by the represented to once again 
"stand for" them, but now, for instance, in terms of shared culture and identities. However, symbolic representation may also be understood with authors like Bourdieu (Wacquant 2005, Stokke 2002) and Anderson (1983) in the wider sense of constructing the demos, the groups and the interests that are being represented and claiming to be a legitimate authority as a representative.

There are two major approaches. ${ }^{8}$ The first may be called the chainof-popular-sovereignty approach. It is typically adhered to by students of political institutions, focusing on formally regulated politics, government and public administration. The second is what will be labelled the directdemocracy approach. This is more common among political sociologists, anthropologists and students of rights and law. They emphasise the importance of informal arrangements and the need for alternative participation through popular movements and lobby groups as well as civic action in for instance neighbourhood groups and associations for selfmanagement.

There are two related tendencies towards deteriorated representation within the chain of popular sovereignty. One is that public matters and resources have been reduced and fragmented under neo-liberalism and globalisation beyond democratic representation. The other tendency is that almost all of the links in the chain itself are tarnished. This is especially with regard to the intermediary representative institutions from civic organisation to political parties. Mass based interest organisations have been radically weakened, most severely those based on class. While public resources and capacities are shrinking, politicians and political parties lose firm and independent popular roots. The privatisation, informalisation, depoliticisation and weakening of the intermediary political institutions generate further distrust in the authorisation of representatives and their mandates. Representative politics is often looked upon as a particularly dirty business characterised by money and personality oriented politics, non-programmatic organisational machines and crooked politicians. This in turn has generated alternative routes. But the various supplementary forms of democracy - by taking matters to court and to institutions in civil society for self-financed self-management and direct participation, pressure and informal contacts - are largely detached from the chain of popular sovereignty. The civic organisations and activists themselves are rarely subject to basic principles of democratic representation, authorisation and accountability. Moreover, communal ethnic and religious organisations as well as families and clans cater to an increasing number of popular worries and needs, typically amongst the weaker sections of the population with insufficient capacities to make use of civic rights. When not claiming equal civic, political and socio-economic rights for all but specific communal privileges, these organisations and solidarities tend to fragment the demos and to undermine democracy. 
While the advantage of the chains-of-popular-sovereignty approach is precision and conceptual consistency in relation to democratic theory, one drawback is thus that contextual differences such as between the exit from organised politics by strong citizens in the North and the marginalisation from organised politics of vulnerable majorities in the South are often neglected. Another weakness is that practices outside the formally recognised chain tend to be set aside such as attempts at participatory governance and struggles over public affairs that have been privatised or informalised.

Unfortunately, however, the direct-democracy approach does not provide a good alternative but rather focus on the other or neglected side of the coin. Interestingly, this is done from two directions, one which is more market oriented, supported by e.g. the World Bank (1997) and in favour of user- and consumer participation (rather than citizenship and popular sovereignty); another advocated by critics of globalisation like Michael Hardt and Antonio Negri (2000) who argue that state and power has been so dispersed and localised that there is no decisive unit left to fight and that increasingly many producers are regulating social relations themselves, so that strong parties and representative democracy are unnecessary and even irrelevant. Both positions support thus the position of Robert Putnam (1993) and others that the "real" demos develops organically from below among self managing and co-operating citizens (thus developing "social capital"), not in relation to ideologies, institutions and political engagement. Hence, representation becomes redundant since the people act directly through the same contacts and associations that have constituted the people in the first place. Further, almost whatever "civic" organisation becomes "parts of the people itself". Hence there is no need to analyse, for instance, differences between organisations that relate to "rights-bearing citizens" and people who lack sufficient capacity to promote their own rights. Further, one does not need to discuss the importance of intermediary variables such as politics and ideology. The fact that Scandinavian democracy and welfare states as well as contemporary participatory budgeting, for instance, have all been politically facilitated and then sustained is conveniently forgotten.

However, many civil society activists are now more anxious than before to legitimate their work in terms of whom they try to represent (Houtzager 2007). Moreover, the new institutions for direct participation such as participatory planning are (just like previous Scandinavian experiences of combining liberal political democracy and interest based representation and cooperation between government and associations) attempts to initiate anew layer of representation between electoral chains of popular sovereignty and associational life and populism on the other. (C.f. Avritzer 2002, Baiocchi 2005, Esping-Andersen 1985, Berman 2006) Yet, a number of questions remain to be answered such as how to guarantee authorisation and accountability, and even more difficult, how to identify and agree on what parts of the demos should control what sections of public affairs on the basis of political equality. 


\section{An integrated framework}

Given that the primacy of popular sovereignty must thus be combined with collective efforts to widen democracy beyond the formal public institutions, the focal point may be democratic representation. The Programme will draw on the inclusive definition of democracy that has already been outlined as a guide for the comprehensive analyses of power and democracy. Hence, there are three basic pillars of a framework for the study of representation: (1) the people (demos), (2) the public matters, and (3) the different intermediary ways of exercising popular control of the input as well as output sides of democracy; i.e. policymaking and implementation. Democratic policy making (input) and implementation (output) need to be representative by, first, being based on the principles of political equality and impartiality and, second, subject to authorisation with mandate and to accountability with transparency and responsiveness. The actual content of what is thus being decided and implemented is due to the will of the demos but must be supportive of the principles of democracy and the absolutely necessary means to develop and apply them. Figure 1 presents a preliminary integrated framework for the study of democratic representation.

Figure 1. An inclusive model for the study of democracy oriented representation

\begin{tabular}{|c|c|c|c|c|c|}
\hline \multicolumn{6}{|c|}{$\begin{array}{l}\text { PUBLIC AFFAIRS } \\
\text { Matters of common concern which may be governed in more or less public ways }\end{array}$} \\
\hline \multirow{2}{*}{$\begin{array}{l}\text { Institutions for } \\
\text { private } \\
\text { governance }\end{array}$} & \multirow{2}{*}{$\begin{array}{l}\text { Institutions for } \\
\quad \text { civic } \\
\text { self-governance }\end{array}$} & \multirow{2}{*}{$\begin{array}{l}\text { Auxiliary state institutions } \\
\text { and institutions for sub- } \\
\text { contracted public governance }\end{array}$} & \multicolumn{3}{|c|}{ Institutions for public government } \\
\hline & & & $\begin{array}{l}\text { The civil and } \\
\text { military administration }\end{array}$ & $\begin{array}{l}\text { The judiciary } \\
\text { and police }\end{array}$ & $\begin{array}{l}\text { The political } \\
\text { executive }\end{array}$ \\
\hline \multicolumn{5}{|c|}{ Institutions for participation/representation at all levels and in all sectors } & $\begin{array}{l}\text { The political legislative } \\
\text { at all levels }\end{array}$ \\
\hline
\end{tabular}

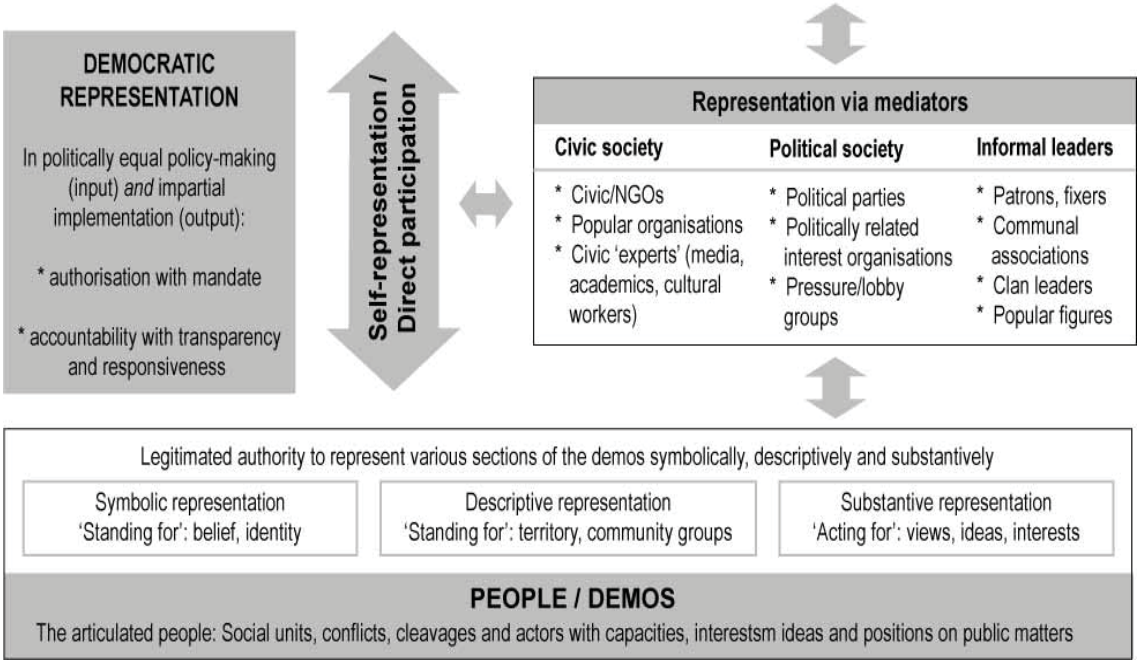


First, the people. As any student of communal politics in general or the Sri Lankan Tamil- and Indonesian Aceh conflicts in particular is well aware of, the definition of the demos can not be taken for granted. Globalisation and the hollowing out of the state (on central but also local level) tend to disintegrate and produce overlapping demos in relation to various issues, spheres and territories. Higher mobility, migration, continued subordination of women, less unified workplaces and increasing separation of workplaces and residence add to the picture as do identity politics. Who are citizens with actual rights and who are instead next to subjects? Who have the right to vote and a say in other ways, and who has not? Who have the right to control certain aspects of the public matters but not other? What is the capacity of various sections of people to voice their views and interests and act accordingly, individually or collectively?

Second, the public affairs that people are supposed to control are also not pre-given. As we know from the definition of democracy, the issue boils down to a dispute about what factors that are intrinsic to develop and sustain democracy. During the third wave, limited democracy has proved possible even under harsh conditions. However, the limitations are severe and it has become equally clear that increased public and popular capacity to promote and use the conventional instruments is necessary; necessary to make political democracy substantial enough to serve as a framework for additional aspirations such as rights based peace and sustainable development. Hence, while it may be obvious that the core institutions for public government include the legislative and its executive, the civil and military administration, the judiciary and the police, it remains a matter of dispute as to whether for instance domestic violence or work environment are part of public government. Similarly it is vital to consider institutions for self-governance such as co-operatives as well as different combinations of private, civic- and public governance and government in the form of joint ventures, auxiliary bodies and sub-contracting. Finally it is particularly important in analysis of countries like Sri Lanka and Indonesia to include both formal and informal institutions and to ask about their capacities in terms of performance as well as their geographical and substantive scope.

Given the general tendencies of less public and more polycentric governance, a particularly crucial issue are the prospects for democratic regulation of more or less privatised institutions of governance rather than reclaiming these institutions, which may not be feasible. Along the top row in Figure 1, privatised collective transportation, schools, or health services, for instance, would thus be subject to democratically decided rules and regulations. ${ }^{9}$ Another basic question is whether or not democratic governance would be conducive to fight corruption and promote environmentally and socially responsible economic growth. There is an urgent need to analyse democratic alternatives to the resurgence of the thesis about the need to promote firm institutions, rule of law and economic development ahead of popular sovereignty by supposedly enlightened authoritarian rule. The same holds true for democratic alternatives to accommodate rebels like 
those in Aceh, rather than by divisive clientelism and "special favours". In the figure on representation, attempts to apply participatory governance to improve responsiveness and accountability (such as attempted at for instance in Brazil; e.g. Baiocchi 2005) would be by more substantial arrangements for participation and representation that are attached to the various institutions for governance (especially the executive ones) and sections of the demos. Further, the renewed interest in learning from old Scandinavian social pacts (c.f. Beckman et.al. 2000, Beckman 2004) may be indicated in terms of triangular relations and agreements (about the exchange between state guaranteed economic growth and collective wage agreements, and universal unemployment- and social welfare schemes) between productive sections of capital within the context of private governance, relevant sections of the institutions for public government, and well organised trade unions and related movements.

Third, the various forms of mediation in-between the demos and the public affairs. The mediation relates both to the input and output side of democracy; to the politically equal generation of policies and to the impartial implementation (the latter of which seems to be positively related to the more universal as opposed to means-tested measures that are applied; c.f. Rothstein and Torell (2005). Arrangements for participation and representation that are related to the different institutions for governance of public matters are in the upper part of the model. This includes not only the elected legislative assemblies and their executives on the central and local levels. There are also, for instance, various possible institutions for consultation and participation in relation to a number of administrative boards and commissions, workers' participation in company management, the meetings of a neighbourhood organisation, or academic self-rule. Most of the introduction of these institutionalised forms of representation may well have been enforced from below through pilot cases and demands on politicians. However, the very implementation tend to be a product of top-down measures and decentralisation, in Scandinavia and Kerala, for instance, on the basis of strong state apparatuses or state-building projects and the legacies of free farmer communities and land reforms respectively. For good and for bad, moreover, these roots and measures in turn have then formed much of the system of representation, including parties, movements and even the constitution of the demos.

Far down in the model, representation is also framed by the different formations and expressions of the demos and the means of representation. The means include the actors and their authorization, responsiveness and accountability - as well as their capacity to voice interests and ideas and act accordingly, ideally on the basis of political equality. On the left side of the model are the forms of self-representation and participation. Strictly speaking, this is the only form of direct democracy, i.e. where no representative is involved. On the right side is the representation via mediators. A basic distinction may be made between mediation via (a) civil society defined as associational life among rights bearing citizens, primarily 
within civic oriented NGOs, local communities, popular organisations, media, academia, and cultural life; (b) informal leaders and non-civicassociations such as patrons, fixers, communal associations, clan leaders and "popular figures"; and (c) political society including political parties, politically related interest organisations and pressure and lobby groups.

One related question is the fate of democracies dominated by clientelism through informal leaders and privileged political financing. Another dilemma (that have been addressed at in thematic studies related to Demos' research; Priyono et. al. forthcoming and Törnquist 2007c and forthcoming) is the weak and generally problematic linkages between on the one hand civic associations (that are often rather small and confined to middle class residents or activists), and more mass based and popular oriented movements. The same applies for the crucial problems of scaling up such linkages and co-operations on various levels and to make an impact within the organised politics tend to be dominated by powerful elites.

\section{Conclusion}

In short, the initial analytical challenge of the PCD programme is to develop a framework that allows for empirical analysis of the problems and options of democratic politics in favour of rights based (social democratic) peace and development in theoretical and comparative perspective.

Analytically, the Programme works in three phases that overlap partially. The first and phase is comprehensive analysis in each of the major contexts (Sri Lanka and Indonesia) of power, conflict and democracy. This phase is brief, as much knowledge is already available, in Indonesia from Demos' survey and in Sri Lanka from the South Asia survey. The initial point of departure for the joint framework for this purpose is that which has been tested out in Demos' studies of the problems and options of Indonesian democracy. This frame in turn combines and expands on, on the one hand, generally accepted theoretical points of departure for assessing democratic institutions, and on the other hand widely acclaimed theories of power and social and political movements to explain the actors' will and capacity to promote and use the institutions. Empirically, moreover, the original framework (which may only partially be possible to apply in Sri Lanka) is based in interviews to gain systematic assessments by grounded and experienced experts in different contexts and sectors around the countries. In the PCD Programme, this will be combined with more conventional data banks, surveys and thematic- and case oriented studies.

The second and major phase includes two steps. One is to identify within the general framework the most essential problems that relate to the dilemmas of depoliticisation, the deficit of democratic representation and the prospects for popular representation and democratic transformation of conflicts - all of which is deemed to be the major causes for the current crisis of democratisation in the global South. The other step is to carry out a 
number of reviews of existing knowledge as well as supplementary specific studies. The more precise analytical framework for the second phase of the programme focuses on democratic representation. The insights from previous collective writings on Politicising Democracy (2004) and Rethinking Popular Representation (forthcoming) are taken as points of departure, in addition to frameworks for studies of transformation of conflicts. The major thrust is to integrate the two separately dominant perspectives - the chain of popular sovereignty approach and the direct democracy approach. This is done by focussing on the construction of the demos, on what parts of the demos that control what parts of the public affairs, and on the problems and options of developing and combining participation and mediation in ways that do not compromise the principles of democratic representation.

The third phase is to continuously update and expand on the initial comprehensive analyses of power, conflict and democracy in each contexts by drawing on the results from the specific studies (during the second step) - and to finally compare the two thus more complete analysis in wider theoretical and international comparative perspective. 


\section{Endnotes}

1 This article grows out of the collective work behind my introductory chapter to the forthcoming anthology (Palgrave) Rethinking Popular Representation, edited by Kristian Stokke, Neil Webster and myself. I am most thankful for valuable comments from Kristian Stokke and the colleagues behind that volume, several of whom are also associated with the PCD programme as well as many of the new PCD group. All the remaining mistakes are my own.

${ }^{2}$ For the details, see the Introduction to this issue of the PCD journal, Törnquist et.al. 2008.

3 The most well know example is probably that of the Freedom House ratings.

${ }^{4}$ The reports by the World Bank (1997) and UNDP (2002) are good examples, but c.f. also scholarly works such as Hadenius (1992).

${ }^{5}$ Evaluations of the survey point to the need to add specific questions on interest based representation and institutions for "direct" participation in policymaking as well as the executive. The 32 means of democracy are described in Samadhi and Warouw's article in this edition.

${ }^{6}$ Within the index (0-100), the relative importance of performance and geographical and substantive scope was deemed to be $50 \%, 25 \%$ and $25 \%$ respectively. Further, the relative importance of formal and informal institutions was deemed to be $70 \%$ and $30 \%$ respectively. Finally the value of the formal institutions was reduced with the proportion of informants stating that no formal institutions existed in the firms place.

7 While the meaning of economic capital may be self evident (and may well be expended by more qualified analysis of the political economy between neoliberalism and state sponsored business under globalisation; see e.g. HarrissWhite 2003, Kohli 2004 and Khan 2005), social capital in mainly about "good contacts", and cultural capital involves information and knowledge. In Demos' survey yet another category has been added to cover the power by way of coercion, including by military force but also mass demonstrations such as the "people power" phenomenon in the Philippines.

8 The following sections draw particularly closely on Törnquist et.al. (forthcoming), which in turn is incepted to the collective work for Harriss et.al (2004) and inspiration from the public discourse on the Norwegian research programme on power and democracy (c.f. Østerud 2003 and 2007) and the working papers by Stokke (2002), Houtzager et.al (2005) and Castiglione and Warren (2005) in addition to the finding out with Demos if and how the framework and concepts would make sense in reality.

9 This is a long established practice of social democratic governance but it has also been tried in scattered local settings in, for instance, the Philippines (e.g. Rocamora 2004 and Quimpo 2004) and in cases such as Brazil, South Africa and the Indian state of Kerala and West Bengal (see e.g. Avritzer 2002, Baiocchi 2003 and 2005, Fung and Wright 2003, Heller 2001, Isaac and Franke (2000), Tharakan 2004, Jones and Stokke 2005, Buhlungu (2006), Ballard, Habib and Valodia (2006), Webster (1992), Rogaly and Harriss White (1999). 


\section{References}

Anderson, Benedict (1983): Imagined Communities, London: Verso.

Avritzer, Leonardo (2002): Democracy and the Public Space in Latin America. Princeton: Princeton University Press.

Baiocchi, Gianpaolo (ed.) (2003). Radicals In Power. The Workers' Party (PT) and experiments in urban democracy in Brazil. London - New York: Zed Books Ltd.

Baiocchi, Gianpaolo (2005): Militants and Citizens. The Politics of Participatory Democracy in Porto Alegre, Stanford: Stanford University Press.

Ballard, R, Habib, A. and Valodia, I. (eds) (2006): Voices of Protest: Social Movements in Post-Apartheid South Africa, Pietermaritzburg: University of KwaZulu-Natal Press.

Beckman, Björn (2004): “Trade unions, institutional reform and democracy: Nigerian experiences with South African and Ugandan comparisons", in John Harriss, Kristian Stokke, and Olle Törnquist (eds.), Politicising Democracy: The New Local Politics of Democratisation, Basingstoke: Palgrave.

Beckman, Björn, Akwetey, Emanuel.O. and Lindstrom, Lars. (2000): Labour unions, social pacts and democratisation. Background Paper to UNRISD Visible Hands. Geneva: United Nations Institute for Social Development.

Beetham, David (1999): Democracy and Human Rights. Oxford: Polity Press.

Beetham, David, Sarah Bracking, Ian Kearton \& Stuart Weir (2002). International IDEA Handbook on Democracy Assessment. The Hague: Kluwer Law International.

Berman, Sheri (2006): The Primacy of Politics: Social Democracy and the Making of Europe's Twentieth Century. New York: Cambridge University Press.

Buhlungu, Sakhela (ed.) (2006): Trade Unions and Democracy. Cosatu workers' political attitudes in South Africa. Cape Town: HSRC Press.

Castiglione, Dario \& Warren, Mark E (2005): “Rethinking Representation: Seven Theoritical Issues" (Prepared for delivery at the Midwest Political Science Association Annual Conference, Chicago, IL, April 6-10, 2005.

Chatterjee, Partha (2004): The Politics of the Governed. Reflections on Popular Politics in most of the World. New York: Columbia University Press.

CSDS 2007: Centre for the Study of Developing Societies, State of Democracy in South Asia, New Delhi: Oxford University Press.

Demos (2008), Törnquist, Olle, Samadhi, Willy P, Kariadi, Syafa'atun et.al. Democracy-Building on the Sand. Advances and Setbacks in Indonesia. Executive and Summary Report from the $2^{\text {nd }}$ National Expert Survey on Problems and Options of Indonesian Democracy 2007-2008, Jakarta: Demos.

Esping-Andersen, Gøsta (1985): Politics against markets. The Social Democratic Road to Power. Princeton: Princeton University Press. 
Fung, Archon and Wright, Erik Olin (2003): Deepening Democracy. Institutional Innovations in Empowered Participatory Governance. The Real Utopias Project IV. London and New York: Verso.

Hadenius, Axel (1992): Democracy and Development. Cambridge: Cambridge University Press.

Hardt, Michael. and Negri, Antonio (2000): Empire. Cambridge: Harvard University Press.

Harriss, John (2006): "Politics is a dirty river". But is there a "new politics" of civil society?'. In, John Harriss, Power Matters: Essays on Institutions, Politics and Society in India, Delhi: Oxford University Press.

Harriss, John, Stokke, Kristian. and Törnquist, Olle. (Eds.) (2004): Politicising Democracy. The New Local Politics of Democratisation. Houndmills: Palgrave.

Harris-White, Barbara. (2003). India Working: Essays on Society and Economy. Cambridge: Cambridge University Press.

Heller, Patrick. (2001). Moving the State: The Politics of Democratic Decentralization in Kerala, South Africa and Porto Alegre. Politics and Society, 29(1), 131-163.

Houtzager, Peter P \& Lavalle, Adrian Gurza \& Harris, John (2005): The Puzzle of the Polity: Citizens, Collective Actors, and States in Large Developing Democracies (Brazil, India, and Mexico). Bellagio Introduction Paper (Preliminary draft).

Houtzager, Peter P, Acharya, Arnab and Gurza Lavalle, Adrián (2007): Associations and the Exercise of Citizenship in New Democracies: Evidence from São Paulo and Mexico City, IDS Working Paper 285, Brighton: University of Sussex.

Isaac, Thomas. M. T with Franke, Richard. W. (2000). Local Democracy and Development, People's Campaign for Decentralized Planning in Kerala. Delhi: Leftward Books.

Jones, Peris and\& Kristian Stokke (eds.) (2005). Democratising Development. The Politics of Socio-Economic Rights in South Africa. Leiden: Koninklijke Brill NV.

Khan, Mushtaq H (2005). "Markets, States and Democracy: Patron-Client Networks and the Case for Democracy in Developing Countries." Democratization, Vol.12 No.5, December.

Kohli, Atul (2004): State-Directed Development: Political Power and Industrialization in the Global Periphery. Cambridge: Cambridge University Press

Mamdani, M. (1996). Citizen and Subject: Contemporary Africa and the Legacy of Late Colonialism. Princeton: Princeton University Press.

Mouzelis, N. P. (1986). Politics in the Semi-Periphery. Houndmills: Macmillan. Pitkin, Hanna Fenichel (1967): The Concept of Representation. Berkeley and Los Angeles: University of California Press.

Priyono, A.E, Samadhi, Willy P, and Törnquist, Olle (2007) Making Democracy Meaningful. Problems and Options in Indonesia. 
Jogjakarta, Jakarta and Singapore: PCD Press, Demos and ISEAS. (1st edition 2005)

Putnam, Robert D. (1993): Making Democracy Work; Civic Traditions in Modern Italy, Princeton, NJ: Princeton University Press.

Quimpo, Nathan (2004) Contested Democracy and the Left in the Philippines after Marcos, Canberra: Australian National University, $2^{\text {nd }}$ edition: the ANU Southeast Asia Studies Monograph Series, 2008.

Rocamora, Joel (2004): "More than Difficult, Short of Impossible: Party Building and Local Governance in the Philippines", in Harriss, John, Stokke, Kristian and Törnquist, Olle (Eds.) (2004), Politicising Democracy. The New Local Politics of Democratisation. Houndmills: Palgrave.

Rogaly, Ben, Harriss-White, Barbara and Bose, Sugatra (1999): Sonar Bangla? Agricultural Growth and Agrarian Change in West Bengal and Bangladesh. New Delhi, Thousand Oaks, London: Sage.

Rothstein, Bo and Torell, Jan. (2005) "What is Quality of Government? A Theory of Impartial Political Institutions. Paper to the conference "Quality of Government: What it is, How to get it, Why it matters", Göteborg, November 17-19, 2005.

Stokke, K. (2002). Habitus, Capital and Fields: Conceptualising the Capacity of Actors in Local Politics. Unpublished paper, Seminar on 'Local Politics and Democratisation in Developing Countries', University of Oslo, March 12.

Tharakan, P.K.M (2004), "Historical Hurdles in the Course of the People's Planning Campaign in Kerala", in Harriss, John, Stokke, Kristian and Törnquist, Olle (Eds.) (2004), Politicising Democracy. The New Local Politics of Democratisation. Houndmills: Palgrave.

Tarrow, S., (1994). Power in Movement. Social Movements, Collective Action, and Politics. Cambridge: Cambridge University Press.

Törnquist, Olle (2002): Popular Development and Democracy, Case Studies with Rural Dimensions in the Philippines, Indonesia, and Kerala. Occasional Papers from SUM, No.3. Centre for Development and the Environment, University of Oslo in cooperation with UNRISD.

Törnquist, Olle (2008a): "Civic Action and Deficit Democracy", Forthcoming in Selle, Per and Prakash, Sanjeev (eds) Beyond Civil Society, London and New York: Routledge.

Törnquist, Olle (2008b): Research-based Democracy Promotion. Learning from an Indonesian Pilot Programme with Demos, in co-operation with UGM and UiO, Report commissioned by the Swedish development Co-operation Agency with the Norwegian Embassy to Jakarta. Oslo. University of Oslo.

Törnquist, Olle (forthcoming): "The Problem is Representation! Towards an Analytical Framework", in Törnquist, Olle, Stokke Kristian and Webster, Neil, Rethinking Popular representation, Palgrave.

Törnquist, Olle, with Bastian, Sunil, Stokke, Kristian and Warouw, Nicolaas, "Introduction to the PCD programme", in The PCD Journal, Vol 1:1. 
UNDP (2002). Human Development Report: Deepening Democracy in a Fragmented World, New York and Oxford: Oxford University Press.

Uyangoda, J. (2005). Conflict, conflict resolution and peace building. An introduction to theories and practices. Department of Political Science and Public Policy, University of Colombo

Uyangoda, J. (2007). Ethnic Conflicts in Sri Lanka: Changing Dynamics. Washington DC: EastWest Center, Policy Studies 32.

Wacquant, Loïc (Ed) (2005): Pierre Bourdieu and Democratic Politics, Cambridge and Malden: Polity Press.

Webster, Neil (1992): "Panchayati Raj In West Bengal: Participation for the People or the Party? Development and Change 23:4.

World Bank (1997): World Development Report 1997: The State in a Changing World. Oxford: Oxford University Press.

Østerud, Øyvind (2003): "Democracy Beyond Borders? The European Case", ch. 8 in Øyvind Østerud et al. (eds.): Power and Democracy. Oslo: Gyldendal Norsk Forlag AS.

Østerud, Øyvind (ed.) (2005): "Special Issue on Norway: The Transformation of a Political System", in West European Politics 28(4).

Østerud, Øyvind (ed.) (2005): "Special Issue on Norway: The Transformation of a Political System", in West European Politics 28(4). 
